\title{
The influence of in-vitro culture and cooling on the survival and development of cow embryos
}

\author{
A. O. Trounson, S. M. Willadsen and L. E. A. Rowson \\ A.R.C. Unit of Reproductive Physiology and Biochemistry, Cambridge, U.K.*
}

\begin{abstract}
Summary. Cow morulae cultured in a phosphate-buffered medium containing serum developed normally and retained viability when transferred to recipients. Unlike earlier cleavage stages, cow blastocysts tolerated cooling to $0^{\circ} \mathrm{C}$ and retained viability after storage for $48 \mathrm{hr}$ at $0^{\circ} \mathrm{C}$ when transferred to recipients.
\end{abstract}

Cow embryos of 8 cells or fewer show normal development when kept for 3-4 days in the oviducts of rabbits (Lawson, Rowson \& Adams, 1972). Cleavage of 8-cell cow embryos in vitro has been obtained by Tervit, Whittingham \& Rowson (1972) but less than $25 \%$ continued development after transfer to recipients (Tervit, 1973). In the present experiments, culture of cow morulae in vitro was examined, and the viability of embryos cultured for $48 \mathrm{hr}$ was determined by transfer to recipients.

Previous experiments have shown that when cow embryos at the 8-cell stage are cooled to $0^{\circ} \mathrm{C}$ they are damaged irreversibly (Wilmut, Polge \& Rowson, 1975) and that at the morula stage of development only a small percentage of embryos survive cooling (Trounson, Willadsen, Rowson \& Newcomb, 1976). In the present experiments, the tolerance of cow blastocysts to cooling and to short-term storage at $0^{\circ} \mathrm{C}$ was examined.

\section{In-vitro culture}

Morulae were recovered on Days 5, 6 and 7 (Day $0=$ day of oestrus) from heifers induced to superovulate as previously described (Trounson et al., 1976). Embryos were collected from donors and handled in Dulbecco's phosphate-buffered saline (PBS), supplemented as described by Whittingham (1971). The composition (per litre) was $8 \mathrm{~g} \mathrm{NaCl}, 2 \mathrm{~g} \mathrm{KCl}, 1 \cdot 15 \mathrm{~g} \mathrm{Na}_{2} \mathrm{HPO}_{4}, 0 \cdot 2 \mathrm{~g} \mathrm{KH}_{2} \mathrm{PO}_{4}$, $0 \cdot 1 \mathrm{~g} \mathrm{CaCl}_{2}, 0 \cdot 1 \mathrm{~g} \mathrm{MgCl}_{2} \cdot 6 \mathrm{H}_{2} \mathrm{O}, 36 \mathrm{mg}$ sodium pyruvate, $1 \mathrm{~g}$ glucose, $4 \mathrm{~g}$ bovine serum albumin, $25 \mathrm{mg}$ Kanamycin sulphate and $5 \mathrm{mg}$ Phenol red. The medium had an osmolarity of $0.295 \mathrm{osmol}$ and a $\mathrm{pH}$ of 7.2 , and after filtering $\left(0.45 \mu \mathrm{m}\right.$ pore size, Millipore) it was stored frozen at $-20^{\circ} \mathrm{C}$. For culture, PBS was supplemented with $20 \%$ fetal calf serum (FCS) and refiltered before use. FCS was used either untreated or after heat treatment $\left(56^{\circ} \mathrm{C}\right.$ for $\left.30 \mathrm{~min}\right)$. Embryos were cultured in small glass test-tubes $(1.5 \times 5.5 \mathrm{~cm})$ sealed with silicone bungs at $37^{\circ} \mathrm{C}$ in $1-2 \mathrm{ml} \mathrm{PBS}+20 \% \mathrm{FCS}$ in air.

Any degenerate embryos were discarded and the remainder were classified as normal or retarded. Retarded embryos were of a cleavage stage $24-48 \mathrm{hr}$ less advanced than expected on the day of recovery from donors; their potential for continued development was considered doubtful. All embryos used for culture were morulae ranging from 16 to 32-cells (Day 5)-60- to 80-cells (Day 7). Any blastocysts obtained from donors on Day 7 were used in other experiments. The cultures lasted for $24,48,72$ or $96 \mathrm{hr}$ and at the end of culture the embryos were examined microscopically. The apparently normal blastocysts with visible embryonic discs were transferred to recipient heifers, used in cooling experiments, or fixed in aceto-ethanol, stained with $1 \%$ Lacmoid and examined by phase-contrast microscopy. All abnormal or degenerate embryos were fixed and stained.

Table 1 shows the development of embryos during culture. Embryos which showed normal development were expanding and hatching blastocysts, and after staining the nuclei appeared to be normal. Embryos which had undergone cleavage, but were retarded in development, were termed partly developed. Degenerate embryos had few normal nuclei and most were pyknotic.

\footnotetext{
* Postal address: Animal Research Station, 307 Huntingdon Road, Cambridge, U.K.
} 
The age of the embryos at the start of culture (Day 5, 6 or 7) had no effect on the proportion that developed to normal blastocysts in culture. Fewer retarded embryos than normal embryos (see Table 1) showed normal development during 24 and $48 \mathrm{hr}$ culture (12 of $44-27 \%$ versus 94 of $131-$ $72 \% ; \chi_{1}^{2}=27 \cdot 3, P<0.001$ ). When the period of culture was extended from 24 to $48 \mathrm{hr}$ (Table 1), a reduction in the proportion of normal blastocysts was observed $\left(82 \%\right.$ versus $62 \% ; \chi_{1}^{2}=5 \cdot 68$, $P<0.05$ ), and the limit to normal development in culture appeared to be between 72 and $96 \mathrm{hr}$ (Table 1). Considerable variation in the developmental capacity in culture was observed between embryos recovered from different donor heifers at the same time and cultured under identical conditions.

Table 1. Development of cow embryos in vitro in phosphate-buffered saline $+20 \%$ fetal calf serum

\begin{tabular}{ccccccc}
\hline $\begin{array}{c}\text { Duration of } \\
\text { culture } \\
(\text { hr) }\end{array}$ & Age of embryo & $\begin{array}{c}\text { Condition of } \\
\text { embryo before } \\
\text { culture }\end{array}$ & $\begin{array}{c}\text { No. of } \\
\text { embryos } \\
\text { cultured }\end{array}$ & $\begin{array}{c}\text { No. } \\
\text { degenerate }\end{array}$ & $\begin{array}{c}\text { No. partly } \\
\text { developed }\end{array}$ & $\begin{array}{c}\text { No. normal } \\
(\%)\end{array}$ \\
\hline 24 & Day 6 \& 7 & Normal & 66 & 7 & 5 & $54(82)$ \\
24 & Day 7 & Retarded & 10 & 6 & 1 & $3(30)$ \\
48 & Day 6 \& 7 & Normal & 65 & 16 & 9 & $40(62)$ \\
48 & Day 6 \& & Retarded & 34 & 20 & 5 & $9(26)$ \\
72 & Day, 5, 6 \& 7 & Normal & 14 & 0 & 3 & $11(78)$ \\
96 & Day 5 \& 6 & Normal & 12 & 6 & 5 & $1(8)$ \\
\hline
\end{tabular}

Transfer of cultured embryos. Twenty-six Day- 6 morulae from 8 donor heifers, which had developed to expanded and hatching blastocysts during culture for $48 \mathrm{hr}$, were transferred to 13 recipients. Each recipient received one embryo per uterine horn on Day 7-9 of the oestrous cycle. Recipients were slaughtered 3-18 weeks after transfer of embryos and the fetuses were recovered by dissection of the uteri. Thirteen normal fetuses were obtained from 8 of the 13 recipient heifers. The overall pregnancy rate and embryo survival was $61 \%$ and $50 \%$ respectively. Two recipients with a single normal fetus also had a partly resorbed fetus, and one recipient had a partly resorbed fetus only. Only 1 of 5 recipients had normal fetuses at slaughter after embryos had been transferred on Day $8 \frac{1}{2}-9$ of the oestrous cycle.

\section{Cooling of cultured embryos}

Only blastocysts were used; they were obtained either directly from donor heifers (Day 7) or after culture of morulae (Day 6 or 7) for $24 \mathrm{hr}$. Embryos were cooled in $1 \mathrm{ml}$ PBS $+20 \%$ FCS in culture tubes at $0.2^{\circ} \mathrm{C} / \mathrm{min}$, or $>10^{\circ} \mathrm{C} / \mathrm{min}$ by direct transfer to an ice-water bath, and kept there for $2 \mathrm{~min}, 30 \mathrm{~min}, 24 \mathrm{hr}$ or $48 \mathrm{hr}$. Embryos were warmed to room temperature by direct transfer of the culture tube to a water bath at $18-21^{\circ} \mathrm{C}$, and cultured for $24 \mathrm{hr}$.

The survival and development of blastocysts after cooling to $0^{\circ} \mathrm{C}$ is shown in Table 2 . The cooling rate had no influence on embryo survival and development. Culture of embryos for $24 \mathrm{hr}$ before cooling appeared to have no detrimental effect on embryo survival. After culture of 10 Day-7 morulae to blastocysts, 8 continued normal development after cooling to $0^{\circ} \mathrm{C}$ for $24 \mathrm{hr}$. However, only $5 / 13$ cultured embryos showed normal development after $48 \mathrm{hr}$ storage at $0^{\circ} \mathrm{C}$ compared to $6 / 10$ embryos obtained direct from donor heifers. As for embryo culture, there was considerable variation in the survival rate after cooling of embryos from different donors.

Transfer of embryos cooled to $0^{\circ} \mathrm{C}$. Twenty blastocysts from 5 donor heifers, stored at $0^{\circ} \mathrm{C}$ for $48 \mathrm{hr}$, were transferred to 10 recipient heifers on Day $6 \frac{1}{2}-8$ of the oestrouscycle. Each recipient received 1 embryo in each uterine horn. Recipients were slaughtered between 12-26 weeks of gestation and the fetuses examined for normality. A total of 8 normal fetuses, from 3 of the donors, were obtained from 6 of the 10 recipients. Eight embryos from the remaining 2 donors failed to develop when transferred to recipients and a further 6 embryos from the same donors, cultured after storage at $0^{\circ} \mathrm{C}$ for $48 \mathrm{hr}$, failed to continue development in vitro. 
Table 2. Development of cow blastocysts in culture for $24 \mathrm{hr}$ after cooling to $0^{\circ} \mathrm{C}$

\begin{tabular}{|c|c|c|c|c|c|c|}
\hline \multirow[b]{3}{*}{ Age of embryo } & \multirow{2}{*}{\multicolumn{2}{|c|}{$\begin{array}{l}\text { Stage of development } \\
\text { before cooling* }\end{array}$}} & \multirow{3}{*}{$\begin{array}{c}\text { Storage } \\
\text { time at } \\
0^{\circ} \mathrm{C}\end{array}$} & \multicolumn{3}{|c|}{ Development in culture after cooling } \\
\hline & & & & & No, partly & \\
\hline & Early & Expanded & & degenerate & developed & normal $(\%)$ \\
\hline Day 6 & 6 & 6 & $2 \mathrm{~min}$ & 5 & 1 & $6(50)$ \\
\hline Day 7 & 12 & 2 & $30 \mathrm{~min}$ & 0 & 1 & $13(92)$ \\
\hline Day 7 & 8 & 10 & $24 \mathrm{hr}$ & 3 & 3 & $12(67)$ \\
\hline Day 7 & 11 & 12 & $48 \mathrm{hr}$ & 6 & 6 & $11(48)$ \\
\hline
\end{tabular}

* In the four groups, 12, 2, 10 and 13 embryos, respectively, had been cultured for $24 \mathrm{hr}$ to the blastocyst stage before cooling.

\section{Discussion}

It is apparent that cow morulae, like sheep morulae (Moore \& Spry, 1972; Trounson \& Moore, 1974), are capable of normal development in phosphate-buffered culture medium supplemented with serum. The majority of normal blastocysts obtained after culture for $48 \mathrm{hr}$ are viable when transferred to recipients. However, embryo survival rates are 8-15\% lower than those reported for direct transfer without culture (Rowson, Lawson \& Moor, 1971). It would appear that selection of recipients which were in oestrus before the donor may be deleterious to the survival of cultured embryos transferred to these animals. Considering both the proportion of embryos that developed in culture and embryo survival after transfer, culture in PBS $+20 \% \mathrm{FCS}$ for $24-48 \mathrm{hr}$ could be used as a method of short-term storage and transport of embryos. Furthermore, culture appears to be a satisfactory method for assessing the viability of embryos after treatments such as cooling or deepfreezing (Willadsen, Trounson, Polge \& Rowson, 1975). FCS does not appear to be an essential ingredient of the culture medium, as consistent development of cow morulae can be obtained in PBS supplemented with $20 \%$ heat-inactivated sheep serum (A. O. Trounson, unpublished observations).

The susceptibility to damage by cooling decreases as the age of the cow embryo increases. Very few 8- to 16-cell embryos survive cooling to $0^{\circ} \mathrm{C}$ and only $30-40 \%$ of Day 5-6 morulae survive cooling (Trounson et al., 1976). A change in the susceptibility to damage by cooling apparently occurs during the period of 1 or 2 days that separates the morula and blastocyst stages. The reason for this change is not known. Determination of a stage of embryo development which is tolerant to cooling is important in relation to the deep-freezing of embryos. In the experiments on cow embryos reported by Willadsen et al. (1975), no morulae survived freezing, whereas some $50 \%$ of blastocysts survived.

Short-term storage of cow blastocysts at $0^{\circ} \mathrm{C}$ for $48 \mathrm{hr}$ appears to be feasible, and this may be useful in particular circumstances. However, decreasing survival rates with increasing storage time at $0^{\circ} \mathrm{C}$ suggests that storage at $0^{\circ} \mathrm{C}$ should be limited to $48 \mathrm{hr}$. In the sheep, storage of embryos for 5 days at $10^{\circ} \mathrm{C}$ has been reported (Kardymowicz, Kardymowicz \& Kremer, 1966), and the storage of cow embryos at temperatures above $0^{\circ} \mathrm{C}$ may give viability for longer periods.

Dalgety Australia Ltd provided a Research Fellowship for A.O.T. and the Milk Marketing Board a Research Fellowship for S.M.W. We thank other members of the Unit for assistance and Professor T. R. R. Mann for reading and discussing the manuscript.

\section{References}

KaRdymowicz, M., Kardymowicz, O. \& KREMER, M. (1966) Successful in vitro storage of sheep ova for five days. Acta biol. cracov., zool. 9, 117-119.

LAwSON, R.A.S., Rowson, L.E.A. \& ADAMS, C.E. (1972) The development of cow eggs in the rabbit oviduct and their viability after re-transfer to heifers. J. Reprod. Fert. 28, 313-315.

MOORE, N.W. \& SPRY, G.A. (1972) The culture of fertilized sheep ova. $J$. Reprod. Fert. $28,145$.

Rowson, L.E.A., LAwson, R.A.S. \& MOoR, R.M. 
(1971) Production of twins in cattle by egg transfer. J. Reprod. Fert. 25, 261-268.

TERVIT, H.R. (1973) Culture and transfer of sheep and cattle ova. Ph.D. thesis, University of Cambridge.

Tervit, H.R., Whittingham, D.G. \& Rowson, L.E.A. (1972) Successful culture in vitro of sheep and cattle ova. J. Reprod. Fert. 30, 493-497.

Trounson, A.O. \& Moore, N.W. (1974) The survival and development of sheep eggs following complete or partial removal of the zona pellucida. $J$. Reprod. Fert. 41, 97-105.

Trounson, A.O., Willadsen, S.M., Rowson, L.E.A. \& NewcomB, R. (1976) The storage of cow embryos at room temperature and at low temperatures. J. Reprod. Fert. 46, 173-178.

WhitTinghaM, D.G. (1971) Survival of mouse embryos after freezing and thawing. Nature, Lond. 233. 125-126.

Willadsen, S.M., Trounson, A.O., Polge, C. \& Rowson, L.E.A. (1975) Deep-freezing of cow embryos. In Proc. EEC Symp. on Egg Transfer in Cattle, Cambridge. Ed. L. E. A. Rowson. Janssen Services, London.

Wilmut, I., Polge, C. \& Rowson, L.E.A. (1975) The effect on cow embryos of cooling to 20,0 and $-196^{\circ}$ C. J. Reprod. Fert. 45, 409-411.

Received 29 December 1975 